\title{
Socially Irresponsible Corporations and Choices of Consumers: Altruism, Retaliation, or Demand for Reparation?
}

\author{
Bryan H. Chen ${ }^{1}$, Mei-Hua Chen ${ }^{1} \&$ Pei-Ni Tai ${ }^{1}$ \\ ${ }^{1}$ Department of Finance, National Changhua University of Education, Taiwan \\ Correspondence: Bryan H. Chen, National Changhua University of Education, Changhua City, Taiwan.
}

Received: December 13, 2017 Accepted: March 28, 2018 Online Published: May 7, 2018

doi:10.5539/ijms.v10n2p47 URL: https://doi.org/10.5539/ijms.v10n2p47

\begin{abstract}
In this study we investigate consumers' perceptions regarding corporate social irresponsibility (CSiR), perceived betrayal, and punishment behaviors (altruistic, retaliatory and demand for reparation behavior). This article examined empirically the relationship between CSiR and punishment behaviors with perceived betrayal as a moderator via PLS-SEM and PROCESS. The results supported three main hypotheses (a) consumers' CSiR perception positively predicted their altruistic, retaliatory and demand for reparation behaviors as well as feelings of perceived betrayal; (b) Consumers' feelings of perceived betrayal positively influenced their altruistic, retaliatory and demand for reparations behaviors; (c) Consumers' feelings of perceived betrayal mediated the relationship between $\mathrm{CSiR}$ and punishment behaviors. Findings suggest that once consumers perceived CSiR events, they tend to perform punishment behaviors to penalize socially irresponsible corporations.
\end{abstract}

Keywords: corporate social irresponsibility, perceived betrayal, punishment behavior, altruistic behavior, retaliatory behavior, demand for reparation

\section{Introduction}

In recent years, corporate social responsibility (CSR) has received increasing attention in academia and practice (Taneja, Taneja, \& Gupta, 2011). In general, CSR represents that businesses abide by existing laws, advocate the promotion of economic growth, and contribute toward ethics, philanthropy, the environment, and stakeholders voluntarily (Dahlsrud, 2008). Extra efforts, such as environmentally friendly technique development, community involvement, and education promotion, for social well-being connect CSR with "doing good" (Lin-Hi \& Muller, 2013).

These behaviors of "doing good" can yield many benefits for an enterprise. First, these behaviors can reduce enterprises' costs and risks: When enterprises are willing to establish positive social relationships and commit to environment protection, the negative attention from the society as well as litigation costs may be reduced; moreover, enterprises can have the opportunity to gain preferential tax agreement and achieve reduced regulations. Second, the behaviors can strengthen legality and corporate reputation: Enterprises conduct philanthropic events to reinforce brand trust; moreover, they adopt cause-related marketing to stimulate sales volume and further improve corporate image. Third, they can establish competitive advantage by providing diverse recruitment strategies to attract more talented people, in addition to supporting the relationship with customers to increase brand loyalty. Fourth, they can create a win-win situation through synergy: By organizing philanthropic events, enterprises can cocreate a virtuous circle of CSR with the public (Carroll \& Shabana, 2010; Kurucz, Colbert, \& Wheeler, 2008).

Lin-Hi \& Muller (2013) highlighted that businesses have the responsibility to do good and avoid bad behaviors, to prevent corporate social irresponsibility (CSiR) behaviors such as cheating consumers, contaminating the environment, and exploiting labor. For example, since 2008-2014, Taiwan has faced several major food safety concerns (i.e., tainted starch, expired food, and gutter oil), which have caused panic among people and dissipated their faith in the management and security mechanisms of the government. Consumers are increasingly questioning the reliability of the so-called conscience products.

The preceding descriptions raise the following questions: How do people make ethical judgments when they perceive social irresponsibility or immoral events? Do they rely on emotions, intuition, reasoning, or cognition to make judgments? Chen \& Chiu (2011) proposed the dual-process model of moral judgment, which postulates 
that after people perceive an unethical behavior, the processes of both cognition and emotion occur simultaneously, consequently leading to personal ethical judgments. Many consumers insist on acting on conscience to make economic decisions based on their moral values, thereby compelling businesses to change their behaviors concerning economic decisions to correspond with the consumers' social values (Valor, 2005). In other words, people's consumption behaviors indicate the identification of the value of moral legitimacy; consumers' perception of a gap between identification and product character (i.e., environmentally unfriendly products, CSiR, and black-hearted products) could lead to more collective consumer protection (Cheng, 2014).

Several researchers have considered how consumers' attribution of CSR motivations affect the linkage between consumers and businesses, as well as and the complex effects of consumers' response to CSR activities (Ellen, Webb, \& Mohn, 2006; Sweetin, Knowles, Summey, \& McQueen, 2013). If consumers are aware of their consumption consciousness and power, they can take direct or indirect actions in favor of or against businesses on the basis of their perceived CSiR behavior (Sweetin et al., 2013). In general, consumers integrate positive and negative information and consider the consequences of response actions; thus, when businesses engage in irresponsible behaviors, consumers are more likely to respond to such businesses by negative word-of-mouth behavior, complaints, boycotts, legal actions, and conduct different types of protests (Grappi, Romani, \& Bagozzi, 2013). The Internet affords convenience and is thus an additional factor; hence, consumers are more willing to punish irresponsible corporate brands (Sweetin et al., 2013). Moreover, when consumers experience failed services, those who feel disappointed express negative word-of-mouth behavior to prevent others from having the same experience, whereas those who are angry express negative word-of-mouth behavior to punish the business (Wang \& Wu, 2013).

In certain cases, even consumers' perceived CSiR behaviors might not induce punishment behaviors immediately. The major determining factor of consumers' punishment behaviors may be the relationship between consumers and biasness, which is similar to a psychological contract; specifically, the relationship can undermine consumers' trust and corporate image. If a business exhibits irresponsible behaviors, consumers may feel negative emotions (e.g., betrayed), which can prompt various actions from the consumers to punish the business (Kucuk, 2010; Sweetin et al., 2013).

In summary, only a few studies have discussed consumer response behaviors from the CSiR perspective; therefore, to address this research gap, the objective of the present study was to provide an improved understanding of how consumers with the knowledge of ethics respond to socially irresponsible companies. Accordingly, this study investigated whether consumers who have perceived CSiR have the feeling of betrayal and whether they exhibit punishment behaviors (altruism, retaliation, or reparation) as a response to penalize the company.

\section{Literature Review and Hypotheses Development}

\subsection{CSR and CSiR}

To elucidate the effect of CSiR on consumers' emotions and response behaviors, understanding the definition and scope of CSR is essential. The concept of corporate social contract emerged in the twentieth century; it suggests that the indirect social obligation of an enterprise is similar to the obligations and relationship between citizens and government. The primary social contract values only the responsibility of profit maximization, and social progress and improvement of life quality are by-products of economic progress (Lantos, 2001). Corporate social contract is considered the predecessor to CSR.

Recently, CSR has been primarily concerned with two perspectives. First, shareholder theory suggests that shareholders are the owners of enterprises; managers manage the enterprise as agents representing the shareholders. Therefore, managers must make decisions on the premise that their primary goal is to maximize shareholders' wealth. Second, stakeholder theory highlights that the social responsibilities of an enterprise must not be limited to maximizing shareholders' wealth; instead, such responsibilities must extend to every stakeholder who is related to the enterprise (Carroll \& Shabana, 2010; Wu, 2014). The present study thus adopts the definition of CSR provided by Van Marrewijk (2003): Enterprises must consider society and the environment in their business operations and the interaction with stakeholders in their business activities. Chih, Miao, and Chuang (2014) revealed that enterprises have a responsibility toward both shareholders and the different stakeholders such as consumers, customers, employees, community, mass society, suppliers, buyers, and the environment.

Lee, Lau, \& Cheng (2013) targeted the food, pharmaceutical, automobile manufacturers, and textile industries and collected 200 paired samples from manufactures and suppliers to examine the relationship between employee rights protection and financial performance. They revealed that the manufactures/suppliers who 
protect employees' right can increase their financial performance in addition to improving their corporate reputation. Moreover, Jeong, Paek, \& Lee (2013) investigated how brand pages can increase consumers' willingness to respond on social network sites. Using CSR strategy (cause-related marketing vs. cause sponsorship), they demonstrated that when cause-related marketing is adopted, consumers not only willingly join the brand page but also invite personal friends to join; thus, cause-related marketing maximizes the marketing effect.

Kemper, Schilke, Reimann, Wang, \& Brettel (2013) gathered data from different countries and industries and tested CSR as a moderator of the relationship between marketing capabilities and firm performance. They revealed that the marketing capabilities of companies with a more favorable CSR positively affect firm performance, but only in a highly competitive industry. Although consumers' expectation of CSR affects firm performance, from consumers' perspective, their consumption behaviors do not necessarily meet their expectations of a company to conduct social responsibility activities. Grimmer \& Bingham (2013) examined the relationships between consumers' perception of environmental performance of a company and mobile phone purchase intention, and they determined that consumers tend to purchase mobile phones from companies with favorable environmental performance. However, Achabou \& Dekhili (2013) investigated French luxury clothing consumers' tendency to purchase luxury products manufactured using recycled materials, and they revealed that although people generally expect the luxury industry to practice sustainable development, the consumers do not prefer purchasing such luxury products. In other words, consumers are more concerned about the quality of luxury products than they are about the company's social responsibility practices.

Taneja et al. (2011) categorized CSR research into five major types. Type one discussed the meaning, definition, and model of CSR (Carroll, 1979, 1999, 2010; Dahlsrud, 2008; Van Marrewijk, 2003); type two identified factors determining CSR (Lange \& Washburn, 2012; Wu, 2014); type three analyzed actions of CSR (Oberseder, Schlegelmilch, \& Murphy, 2013; Babiak \& Trendafilova, 2011; Bravo, Matute, \& Pina, 2012); type four identified the effects of CSR on stakeholders and financial performance (Chih et al., 2014; Lombart \& Louis, 2014; Lu, Chau, Wang, \& Pan, 2014; Oberseder et al., 2013); type five explored the measurement tools of corporate social performance (Giannarakis, Litinas, \& Theotokas, 2011; Turker, 2009; Wood, 2010; Wagner, Bicen, \& Hall, 2008). Extensive research has been conducted on CSR; however, little research has addressed the concerns of CSR (i.e., CSiR), which is a major gap in consumer behavior research.

According to the marketing literature, the pioneering study on CSiR was published in the Journal of Business Research in 1977 by Armstrong (cited as Murphy \& Schlegelmilch, 2013); this study introduced researchers to the unfamiliar concept of CSiR. Lin-Hi \& Muller (2013) defined CSiR as the action that leads businesses into bad situations and/or undermines other participants. Jones, Bowd, \& Tench (2009) suggested that CSR and CSiR are two separate concepts. Enterprises have been criticized for irresponsible behaviors such as contaminating the environment, exploiting labor, cheating consumers, and causing damage to suppliers (Murphy \& Schlegelmilch, 2013). Wu (2014) reported that cost pressure and government corruption are two major factors affecting the possibility of enterprises practicing socially irresponsible behaviors. In other words, enterprises lose customers when they increase the price of a product, and this compels them to reduce their costs (i.e., reduce the personnel cost or jerry-build products) to maintain the price; such cost reduction can stimulate additional irresponsible behaviors.

Groening \& Kanuri (2013) studied investors and stakeholders' responses to positive and negative corporate social events, and they revealed that respondents in both categories have varying perceptions: When stakeholders have a positive perception of positive corporate social events, investors may not reward the enterprise and even provide a negative abnormal return to punish the enterprise. However, when stakeholders have a negative perception of negative corporate social events, investors may not punish the behavior, and in certain cases, they may reward the enterprise and provide a positive abnormal return.

Perks, Farache, Shukla, \& Berry (2013) combined legitimacy theory and the theory of impression management to investigate how organizations promote CSR strategies through print advertisements and to identify organizations' social and environmental responsibility behaviors. They demonstrated that organizations using different strategies of impression management, such as informing CSR, changing perceptions of and diverting attention from CSiR, and engaging in organizational behaviors appeared legitimate in CSR advertisements.

Murphy \& Schlegelmilch (2013) combined and categorized research related to CSR and CSiR into consumer viewpoint (Grappi et al., 2013; Oberseder et al., 2013; Skarmeas \& Leonidou, 2013; Sweetin et al., 2013), financial/investing viewpoint (Groening \& Kanuri, 2013; Herzig \& Moon, 2013; Lee et al., 2013), marketing viewpoint (Achabou \& Dekhili, 2013; Jeong et al., 2013; Perks et al., 2013), environmental viewpoint (Grimmer 
\& Bingham, 2013; Oberseder et al., 2013), concepts and theories (Armstrong \& Green, 2013; Arnold \& Valentin, 2013; Lin-Hi \& Muller, 2013; Prasad \& Holzinger, 2013; Windsor, 2013). As mentioned, the present study investigates consumers' responses to $\mathrm{CSiR}$ behaviors; therefore, it is categorized as consumer viewpoint research.

\subsection{Perceived CSiR and Consumer Response Behavior}

Consumer behavior refers to the observable behaviors that consumers or purchase decision makers perform at product or service markets; it represents the dynamic interactions among affection, cognition, behavior, and environment that emerge when people perform exchanging behaviors in their daily lives (American Marketing Association [AMA], 2014). People's thoughts, feelings, and behaviors are continuously changing; therefore, when varying information unceasingly stimulates consumers, their response behaviors become a different dynamic process. For example, when consumers perceive that a certain enterprise has contributed to a local community, such CSR activities affect consumers' purchase intention (Lee \& Shin, 2010). Grappi et al. (2013) used variables such as virtue, negative word-of-mouth, and protest behavior to investigate how consumers with negative moral emotions respond to CSiR behaviors. They determined that the effects of consumers' negative moral emotions (i.e., contempt, anger, and disgust) differ from personal virtue, and that these emotions directly affect consumers' negative word-of-mouth and protest behaviors.

Oberseder et al. (2013) compared CSR practices and consumers' perceptions, and they found that the CSR dimensions most valued by consumers were customers, employees and the environment, and consumer-perceived CSR practices such as fair treatment of customers, reasonable prices, information transparency, healthy products, consultation and complaint management, favorable working conditions, reasonable salary, career development and continuing education, diversity and nondiscrimination statement, or family support services. However, the question as to whether consumers truly believe enterprises' claims that they fulfill social responsibilities warrants exploration. Skarmeas \& Leonidou (2013) addressed consumers' skepticism toward CSR, and they revealed that attributions of egoistic- and stakeholder-driven motives cause skepticism among consumers; nevertheless, values-driven attributions repress skepticism. Moreover, CSR skepticism damages company equity, declines resistance to negative information about the company, and stimulates negative word-of-mouth behavior.

When enterprises do not fulfill consumers' expectations, consumers' response behaviors can be categorized into two types. The first type involves negative word-of-mouth behaviors: Consumers express emotions (disgust, disagreement, or contempt) when enterprises perform socially irresponsible actions; in other words, when consumers' rights are violated, they not only express dissatisfaction or anger through negative word-of-mouth behavior (Grappi et al., 2013) but also punish the enterprise through malicious talks and by recommending rival's products or vilification (Wang \& Wu, 2013). The second type involves protest behaviors: Consumers engage in such behaviors to counter and stop an enterprise's unethical behaviors (Grappi et al., 2013), such as boycotting, using blogs to write against the enterprise, watching over, using legal action against the enterprise, and filing complaints (Cheng, 2014; Joireman, Gregoire, Devezer, \& Tripp, 2013; Sweetin et al., 2013).

To measure consumers' perceptions of CSiR, Wagner et al. (2008) developed a scale of CSiR in the context of the retailing industry to determine which corporate behaviors are perceived as irresponsible by consumers. They identified the following 14 major CSiR factors: natural environment, local businesses, foreign economies, local employment, societal rules, employee benefits, employee wages, local working conditions, employee discrimination, foreign labor, sales practices, dishonesty, offensive material, and pricing policies. In addition, they encouraged future researchers to investigate the effects of CSiR by combining consumers' perceptions and purchase behaviors.

Sweetin et al. (2013) adopted scenarios of socially responsible, socially irresponsible, and environmentally friendly to examine consumers' willingness to punish, willingness to reward, brand attitude, and purchase intention. They found that consumers are not only willing to punish CSiR brands but also reduce their purchase intention. Marylyn \& Ahmad (2001) reported that although consumers describe themselves as willing to support ethical enterprises and punish unethical enterprises, ethical considerations may not influence their purchase decision and behaviors. Consistent with the aforementioned studies, the present study uses unethical behaviors as CSiR events. Furthermore, in accordance with Gregoire \& Fisher (2008) and Wetzer, Zeelenberg, \& Pieters (2007), the present study categorizes punish behaviors by severity into altruistic and retaliatory behaviors and demand for reparations.

Altruism is a motivation to increase individual or others' well-being (Batson, 1994). For example, people with altruistic goals are willing to share their consumption experiences with others for free (Cheung \& Lee, 2012). 
Wang \& Wu (2013) indicated that according to the concept of altruism, most Taiwanese consumers tend to express negative word of mouth after experiencing service failures. The present study assumes that altruism behaviors represent the action consumers perform to prevent others from making the same mistake. Thus, the following hypothesis was proposed:

H1. Consumers' CSiR perception positively influences their altruism behavior.

When a group of frustrated and powerless consumers have thoughts of punishing enterprises, long-term negative influences are generated. Moreover, if the management does not resolve consumers' concerns in time, it can trigger a severe public crisis and compel consumers to engage in actual punish behaviors (Bunker \& Ball, 2009; Sweetin et al., 2013). Retaliations are actions to punish and cause problems for enterprises that have hurt consumers' feelings (Bechwati \& Morrin, 2003; Gregoire \& Fisher, 2008). Hence, the following hypothesis was proposed:

H2. Consumers' CSiR perception positively influences their retaliatory behavior.

Demand for reparations is a positive justice-restoring mechanism used to compensate consumers when they experience service or product failures (Gregoire \& Fisher, 2008; Walster, Berscheid, \& Walster, 1973). Therefore, on the basis of the concept of consumer response behavior, the following hypothesis was proposed:

H3. Consumers' CSiR perception positively influences their demand for reparations.

\subsection{Perceived CSiR, Perceived betrayal, and Consumer Response Behavior}

Trust plays a major role in the relationship between consumers and enterprises (Schoorman, Mayer, \& Davis, 2007). Generally, a relationship with trust comprises three elements: interdependence between an individual and group/organization, a vulnerable party, and a party with positive expectations or trust (Koehler \& Gershoff, 2003). According to the concept that the relationship between consumer trust and corporate brand is similar to a psychological contract, if the relationship cannot reach consumers' goal, they may punish the enterprise by performing various actions, thereby reducing the identification of the brand and purchase intention (Kucuk, 2010; Sweetin et al., 2013).

Perceived betrayal implies that consumers have identified that the enterprise purposely violates the relationship and consumer regulations (Elangovan \& Shapiro, 1998; Gregoire \& Fisher, 2008). The enterprise betrayal behaviors identified by consumers include cheating, taking advantage of customers, perfidy, exploitation, and divulging of personal information (Elangovan \& Shapiro, 1998). Koehler \& Gershoff (2003) determined that based on punishment attribution and negative emotions, people's responses to betrayal behaviors are stronger than those to bad behaviors, which do not violate commitment.

Different types of perceived betrayal cause negative emotions in people, who often respond to the betrayer through alienation or punishment (Koehler \& Gershoff, 2003). According to Gregoire \& Fisher (2008), consumers are eager to attempt any means (even retaliatory behavior) to restore justice when they feel betrayed; thus, perceived betrayal is a major motive for consumers to exhibit retaliatory behavior and demand for reparations. Hence, assuming that $\mathrm{CSiR}$ is the violation of the relationship and regulations and perceived betrayal is consumers' identification of enterprises that purposely violate the relationship and regulations (Elangovan \& Shapiro, 1998; Gregoire \& Fisher, 2008), this study proposed the following hypotheses:

H4. Consumers' CSiR perception positively influences their feelings of perceived betrayal.

H5. Consumers' feelings of perceived betrayal positively influences their (a) altruistic behavior, (b) retaliatory behavior and (c) demand for reparations.

H6. Consumers' feelings of perceived betrayal mediates the relationship between (a) CSiR and altruistic behavior, (b) CSiR and retaliatory behavior and (c) CSiR and demand for reparations.

Extending on the literature on $\mathrm{CSiR}$ and consumer response behavior, this study proposes a conceptual model (Figure 1) for examining the possible relationships among perceived CSiR, perceived betrayal, and consumer response behaviors and also tests perceived betrayal as a mediator of perceived CSiR and consumer response behaviors.

\section{Method}

\subsection{Sample and Data Collection}

The sample comprised 321 people enrolled in an Executive Master in Finance program in Taiwan, who mostly took business ethics courses and had the ethical knowledge to judge unethical behaviors. Through a survey questionnaire, the respondents were asked about their perceptions of CSiR descriptions and the response 
behaviors that they may perform. The respondents provided their demographic information. The questionnaire was completed in approximately $10 \mathrm{~min}$. The participants represented three areas (northern, central and southern Taiwan) and 33 universities. After the respective program offices were contacted, the questionnaire package was mailed to 20 universities. A total of 321 participants responded to the survey, and only 6 of them did not provide complete data and were thus excluded from the sample; the final sample size was 315 . The demographic characteristics of the sample are outlined as follows: Of the respondents, $43.8 \%$ were males and $56.2 \%$ were females; $32.4 \%$ were in management positions and $67.6 \%$ were not; $18.7 \%$ were aged younger than 25 years, $34.6 \%$ were aged $25-30$ years, $31.1 \%$ were aged $36-45$ years, $13.3 \%$ were aged $46-55$ years, and $2.2 \%$ were aged older than 56 years; $80.6 \%$ claimed that they paid attention to CSR information or news.

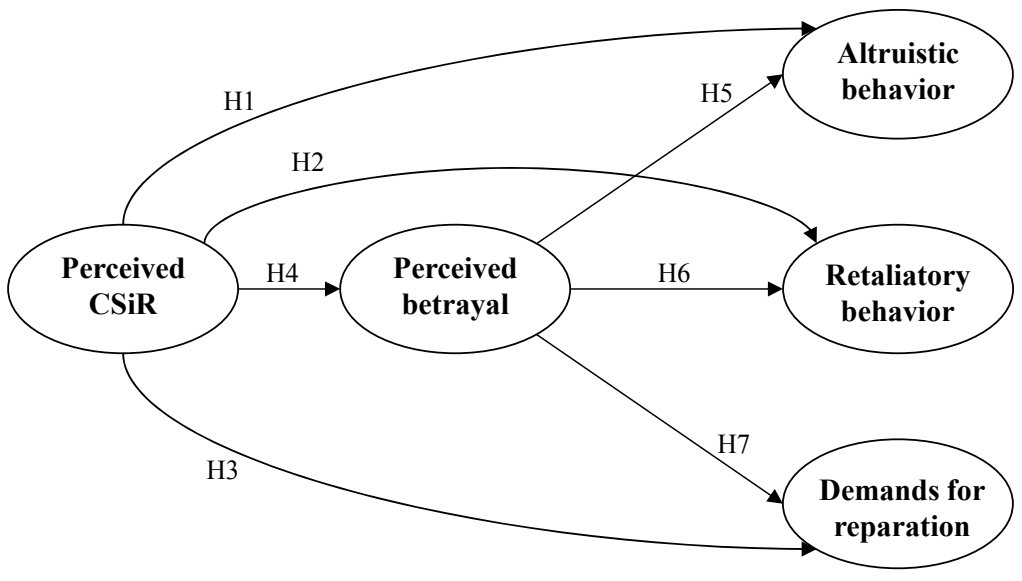

Figure 1. Conceptual model

\subsection{Measures}

In Section 1, CSiR descriptions were developed to measure CSiR perceptions and perceived betrayal. A 13-item perceived CSiR scale was adopted from the study by Wagner et al. (2008); the items were modified to 13 CSiR scenarios, and they demonstrated high internal reliability (Cronbach's $\alpha=.888$ ). Perceived betrayal was measured using the two-item scale developed by Gregoire and Fisher (2008). The two items were integrated into the CSiR scenarios, and they demonstrated high internal reliability (Cronbach's $\alpha=.967$ ). Respondents responded to a series of multi-item Likert measures on a 5-point scale, ranging from 1 (strongly disagree) to 5 (strongly agree).

In Section 2, consumer response behavior scales comprised altruistic behavior, retaliatory behavior, and demands for reparation. A three-item altruistic behavior scale was adapted from the study by Wetzer et al. (2007) and modified; the scale had high internal reliability (Cronbach's $\alpha=.874$ ). Three-item scales for retaliatory behavior and demand for reparations, respectively, were adapted from the study by Gregoire and Fisher (2008) and modified; both scales had high internal reliability (Cronbach's $\alpha=.792$ and .911 , respectively). Respondents responded to a series of multi-item Likert measures on a 5-point scale, ranging from 1 (strongly disagrees) to 5 (strongly agree). Finally, the demographic variable comprised gender, job position, age, and attention to CSR news.

\subsection{Data Analysis}

To test the conceptual model, this study uses partial least squares (PLS), a variance-based structural equation modeling (SEM) method. PLS is an appropriate method for this study due to the following reasons (Ringle, Sarstedt, \& Straub, 2012; Urbach \& Ahlemann, 2010): First, the focus of the study is the prediction of dependent variables (consumer punishment behaviors). Second, the construct of perceived betrayal and retaliatory behavior are each composed of two items. Third, the complexity of model (three outcomes). This study uses SmartPLS software for measurement model and structural model analyses as well as PROCESS software for mediating effect and SPSS21 for descriptive demographic data. 


\section{Results}

\subsection{Descriptive Statistics}

Consumers' characteristics are presented in Table 1. The mean value for perceived CSiR was $4.35(\mathrm{SD}=.69)$, that for perceived betrayal was $3.98(\mathrm{SD}=.68)$, that for altruistic behavior was $3.99(\mathrm{SD}=.81)$, that for retaliatory behavior was $3.90(\mathrm{SD}=.82)$, and that for demand for reparations was $3.82(\mathrm{SD}=.85)$.

Table 1. Descriptive statistics of participants

\begin{tabular}{lll}
\hline & $\mathrm{N}$ & Valid percentage (\%) \\
\hline Gender & & \\
Male & 138 & 43.8 \\
Female & 177 & 56.2 \\
Age & & \\
Under 25 years old & 59 & 18.7 \\
$25-35$ years old & 109 & 34.6 \\
$36-45$ years old & 98 & 31.1 \\
46-55 years old & 42 & 13.3 \\
above 56 years old & 7 & 2.2 \\
Job position & & \\
The management & 102 & 32.4 \\
Staff & 213 & 67.6 \\
CSR attention & & \\
Yes & 254 & 80.6 \\
No & 61 & 19.4 \\
\hline
\end{tabular}

\subsection{The measurement Model_-Validity and Reliability}

Convergent validity was assessed with three metrics: average variance extracted (AVE), composite reliability (CR), and Cronbach's Alpha. As shown in Table 2, all of the convergent validity metrics were evidently greater than proposed in relevant literature-AVE should be greater than 0.5, CR greater than 0.7 (Fornell \& Larcker, 1981), and Cronbach's Alpha should be greater than 0.7 (Peterson, 1994).

Table 2. Convergent validity

\begin{tabular}{|c|c|c|c|c|c|c|c|}
\hline Construct & Indicator & Loading & T-value & $\mathrm{CR}$ & AVE & $R^{2}$ & Cronbach's alpha \\
\hline \multirow[t]{5}{*}{$\mathrm{CSiR}$} & CSiR1 & 0.826 & 31.808 & 0.918 & 0.691 & & 0.888 \\
\hline & CSiR2 & 0.823 & 29.209 & & & & \\
\hline & CSiR3 & 0.855 & 36.200 & & & & \\
\hline & CSiR4 & 0.826 & 29.402 & & & & \\
\hline & CSiR5 & 0.825 & 32.167 & & & & \\
\hline \multirow{2}{*}{ P.betrayal } & PB1 & 0.985 & 314.112 & 0.984 & 0.968 & 0.339 & 0.967 \\
\hline & PB2 & 0.983 & 258.109 & & & & \\
\hline \multirow[t]{3}{*}{ Altruistic } & ALT1 & 0.869 & 36.889 & 0.922 & 0.798 & 0.270 & 0.874 \\
\hline & ALT2 & 0.924 & 77.988 & & & & \\
\hline & ALT3 & 0.886 & 44.620 & & & & \\
\hline \multirow[t]{2}{*}{ Retaliaroty } & RET1 & 0.889 & 38.980 & 0.905 & 0.826 & 0.296 & 0.792 \\
\hline & RET2 & 0.929 & 105.064 & & & & \\
\hline \multirow[t]{3}{*}{ Reparation } & REP1 & 0.905 & 57.089 & 0.944 & 0.848 & 0.249 & 0.911 \\
\hline & REP2 & 0.946 & 108.633 & & & & \\
\hline & REP3 & 0.911 & 49.993 & & & & \\
\hline
\end{tabular}

Discriminant validity was first assessed by comparing the squareroot of the AVE of each construct to all of the correlations between it and other constructs (Fornell \& Larcker, 1981), where all of the square root of the AVEs should be greater than any of the correlations between the corresponding construct and another construct. Second, we assessed discriminant validity by confirming that all items corresponding to a specific construct loaded higher than with any other construct (see Table 3). These two tests indicated that discriminant validity and reliability were acceptable. 
Table 3. Discriminant validity

\begin{tabular}{llllll}
\hline & Altruistic & CSiR & Reparation & Retaliaroty & P.betrayal \\
\hline Altruistic & $\mathbf{0 . 8 9 3}$ & & & & \\
CSiR & 0.490 & $\mathbf{0 . 8 3 1}$ & & & \\
Reparation & 0.615 & 0.418 & $\mathbf{0 . 9 2 1}$ & & \\
Retaliaroty & 0.734 & 0.520 & 0.586 & $\mathbf{0 . 9 0 9}$ & \\
P.betrayal & 0.427 & 0.582 & 0.465 & 0.432 & $\mathbf{0 . 9 8 4}$ \\
\hline
\end{tabular}

\subsection{The Structural Model - Hypotheses Testing}

The path model accounted for $33.9 \%$ of the variance of perceived betrayal as well as $27 \%$ of altruistic behavior, $29.6 \%$ of retaliatory behavior and $24.9 \%$ of demands for reparation. The standardized PLS path coefficients for testing the structural model are shown in Figure 2. The results of the analysis supported all of the hypotheses. Perceived CSiR was positive associated with altruistic behavior (H1), retaliatory behavior (H2) as well as demands for reparation (H3) and perceived betrayal (H4). The hypotheses that perceived betrayal would be positively associated with altruistic behavior (H5) as well as retaliatory behavior (H6) and demands for reparation (H7) were also supported, however, the effect is quite small but still significant (see Figure 2).

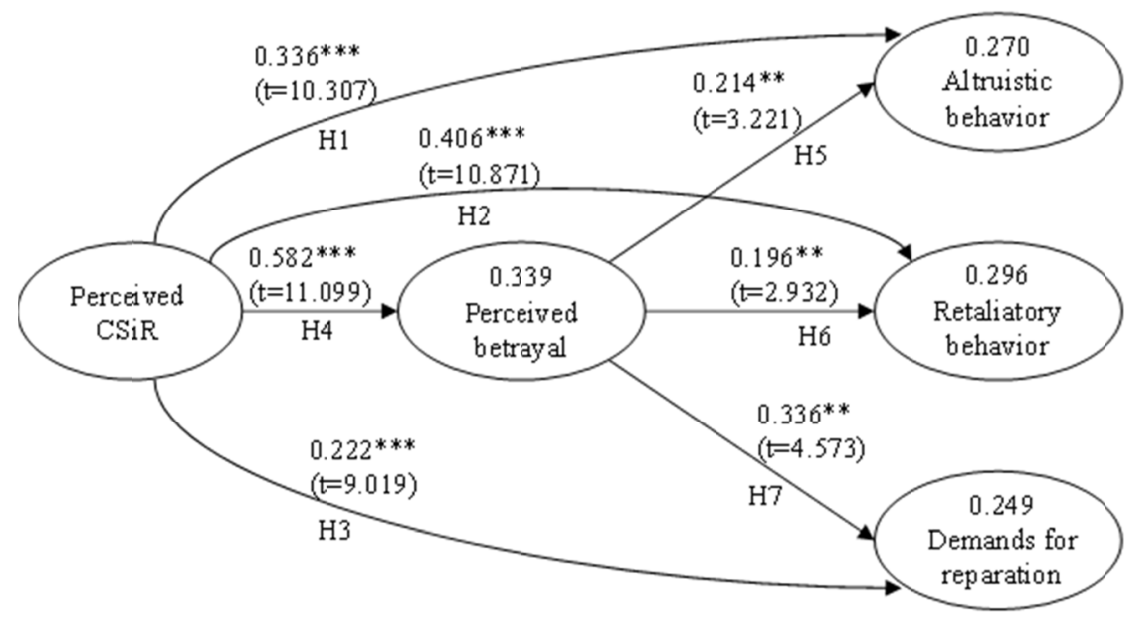

Figure 2. Structural model

Note. $* * * p<0.001, * * p<0.01$.

As shows in Table 4, there is direct relationship between CSiR and altruistic behavior (Alt) $\left(c^{\prime}=0.406 ; \mathrm{t}=\right.$ 5.767), CSiR and retaliatory behavior (Ret) $\left(c^{\prime}=0.495 ; t=6.825\right), C S i R$ and demands for reparation (Rep) (c' $=0.268 ; \mathrm{t}=3.606$ ), respectively. In addition, $\mathrm{a} 1$ and $\mathrm{b}$, as direct effects, in three types of behaviors are all significant. This is a first step to prove the existence of an indirect effect of CSiR on altruistic behavior, retaliatory behavior and demands for reparation via perceived betrayal (PB) as a mediator. Table 5 shows that the significant indirect effect is $0.154,0.137,0.242$, respectively $(\mathrm{a} 1 \times \mathrm{b})$. This result supports H8a, H8b and H8c, that consumers' perception of betrayal is partially mediating the relationships between CSiR and punishment behaviors (see Figure 3).

Table 4. Mediation analysis

\begin{tabular}{|c|c|c|c|c|c|c|}
\hline Behavior 1 & & Behavior 2 & & Behavior 3 & & \\
\hline $\begin{array}{l}\mathrm{R}_{\mathrm{PB}}^{2}=.340 \\
\mathrm{R}_{\text {Alt }}^{2}=.261\end{array}$ & & $\begin{array}{l}\mathrm{R}_{\mathrm{PB}}^{2}=.340 \\
\mathrm{R}_{\mathrm{Ret}}^{2}=.287\end{array}$ & & $\begin{array}{l}\mathrm{R}_{\mathrm{PB}}^{2}=.340 \\
\mathrm{R}_{\mathrm{Rep}}^{2}=.248\end{array}$ & & Support \\
\hline $\begin{array}{l}\mathrm{H} 8 \mathrm{a}: \mathrm{CSiR} \rightarrow \text { Alt } \\
=c\end{array}$ & $.406^{* * *(5.767)}$ & $\begin{array}{l}\mathrm{H} 8 \mathrm{~b}: \mathrm{CSiR} \rightarrow \mathrm{Ret} \\
=c\end{array}$ & $.495 * * *(6.825)$ & $\begin{array}{l}\text { H8c:CSiR } \rightarrow \text { Rep } \\
=c\end{array}$ & $.268 * * *(3.606)$ & Yes \\
\hline $\begin{array}{l}\mathrm{CSiR} \rightarrow \mathrm{PB}= \\
\text { al }\end{array}$ & $.570 * * *(12.687)$ & $\begin{array}{l}\mathrm{CSiR} \rightarrow \mathrm{PB} \\
=a 1\end{array}$ & $.570 * * *(12.687)$ & $\mathrm{CSiR} \rightarrow \mathrm{PB}=a 1$ & $.570 * * *(12.687)$ & \\
\hline $\begin{array}{l}\mathrm{PB} \rightarrow \text { Alt } \\
=b\end{array}$ & $.270 * * *(3.756)$ & $\begin{array}{l}\mathrm{PB} \rightarrow \text { Ret } \\
=b\end{array}$ & $240 * *(3.242)$ & $\begin{array}{l}\mathrm{PB} \rightarrow \mathrm{Rep} \\
=b\end{array}$ & $.425^{* * *}(5.598)$ & \\
\hline Sobel test & $\mathrm{Z}=3.592, p=.000$ & Sobel test & $\mathrm{Z}=3.132, p=.002$ & Sobel test & $\mathrm{Z}=5.108, p=.000$ & \\
\hline
\end{tabular}


Table 5. Mediating effects

\begin{tabular}{llllll}
\hline & & & \multicolumn{2}{c}{ Bias corrected bootstrap 95\% confidence intervel } \\
\hline Behavior & Mediator & Indirect effect & Boot SE & Lower & Upper \\
Alt & PB & 0.154 & 0.044 & 0.075 & 0.249 \\
Ret & PB & 0.137 & 0.045 & 0.052 & 0.230 \\
Rep & PB & 0.242 & 0.061 & 0.134 & 0.378 \\
\hline
\end{tabular}

Note. bootstrapping based on $\mathrm{n}=5000$ subsamples. PB: perceived betrayal; Alt: altruism behavior; Ret: retaliatory behavior; Rep: demands for reparation.

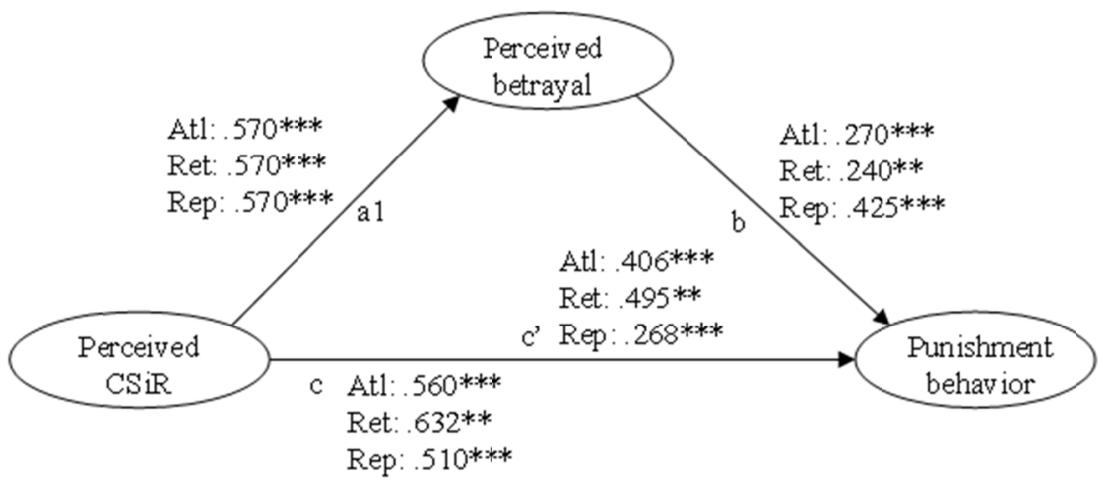

Figure 3. Structural model of mediation

Note. ${ }^{* * *} p<0.001, * * p<0.01$.

\section{Discussion}

\subsection{Major Findings and Implications}

The main focus of the study was to provide insights for how consumers with the knowledge of ethics respond to socially irresponsible companies through consumers' punishment behaviors (altruistic, retaliatory behavior and demands for reparation), and whether consumers' perception of betrayal as a mediator within this relationships. First, this study shows that consumers' perception of CSiR positively and significantly influences consumers' altruistic behavior, retaliatory behavior and demand for reparations. The findings complement a rising body of consumer behavior literature on the consumer' punishment behaviors. Consistent with previous studies (e.g., Cheng, 2014; Grappi et al., 2013; Sweetin et al., 2013; Wang \& Wu, 2013) consumers tend to penalize socially irresponsible companies. Moreover, consumers are willing to punish socially irresponsible companies through altruism behavior (i.e., helping other consumers to avoid making the same mistake), retaliation behavior (i.e., negative word-of-mouth and boycott) and demand for reparation (complaining to the consumer agency). Instead of the direct effects of perceived CSiR, this study took into account the consequences of perceived betrayal and tested the direct and indirect effects of perceived betrayal on CSiR and punishment behaviors.

Second, our findings suggest that consumers' perception of CSiR positively and significantly influences consumers' perception of betrayal. The enterprise violated the relationship with consumers when they acting social irresponsibly, which means the psychological contract between a company and consumers is broken (Elangovan \& Shapiro, 1998; Gregoire \& Fisher, 2008). It seems compatible with our finding. Moreover, perception of betrayal leads consumers to penalize socially irresponsible companies by altruistic behavior, retaliatory behavior and demand for reparations, it appears to be consonant with Gregoire \& Fisher's (2008) and Koehler \& Gershoff's (2003) argument. Perception of betrayal would trigger consumers' intense negative emotion, and their sense of betrayal may make them more willingly to penalize traitors (socially irresponsible companies) via punishment behaviors.

Third, the results also indicate that consumers' perception of betrayal is partially mediating the relationships between $\mathrm{CSiR}$ and each punishment behaviors (altruism, retaliation, or reparation). As Koehler \& Gershoff (2003) mentioned, people react to betrayal behaviors with punitive punishments and negative affect. Our results are in line with Gregoire \& Fisher's (2008) findings that consumers are willing to attempt any means to restore justice when they feel betrayed, hence, perceived betrayal could be one of the motives for consumers to perform punishment behaviors. For socially irresponsible companies, CSiR events that damage a company's relationship 
between consumers can have a significant financial effect on its sales and last for a long time. However, corporations should note that CSR practices does not guarantee the consumers' purchase behavior. But when consumers discovery a company's CSiR action, punitive punishments are they most likely to execute with the company.

\subsection{Limitations and Suggestions for Future Studies}

While this research provides answers to some questions about the consequences of CSiR events from consumers' perspective, it has limitations. This study is limited in that it uses a sample of a Taiwan resident population in three areas. Consumers' response behaviors may be different given alternative cultural in different countries. This study's support for the hypothesis and its findings provides possibilities for future research. Future research should add consumers' emotions and motivations as antecedents to predict punishment behaviors, as well as examine whether consumers' emotions and motivations are related to their actual punishment behaviors as mediators. Lastly, future research should consider whether consumers' moral norm is an effective predictor to predict punishment behaviors.

\section{References}

Achabou, M. A., \& Dekhili, S. (2013). Luxury and sustainable development: Is there a match? Journal of Business Research, 66(10), 1896-1903. https://doi.org/10.1016/j.jbusres.2013.02.011

American Marketing Association. (2014). Dictionary. Retrieved from https://www.ama.org/resources/Pages/Dictionary.aspx?dLetter=C

Armstrong, J. S., \& Green, K. C. (2013). Effects of corporate social responsibility and irresponsibility policies. Journal of Business Research, 66(10), 1922-1927. https://doi.org/10.1016/j.jbusres.2013.02.014

Arnold, D. G., \& Valentin, A. (2013). Corporate social responsibility at the base of the pyramid. Journal of Business Research, 66(10), 1904-1914. https://doi.org/10.1016/j.jbusres.2013.02.012

Babiak, K., \& Trendafilova, S. (2011). CSR and environmental responsibility: Motives and pressures to adopt green management practices. Corporate Social Responsibility and Environmental Management, 18, 11-24. https://doi.org/10.1002/csr.229

Batson, C. D. (1994). Why act for public goods? Four answers. Personality and Social Psychology, 20(5), 603-610. https://doi.org/10.1177/0146167294205016

Bechwati, N. N., \& Morrin, M. (2003). Outraged consumers: Getting even at the expense of getting a good deal. Journal of Consumer Psychology, 13(4), 440-453. https://doi.org/10.1207/S15327663JCP1304_11

Bravo, R., Matute, J., \& Pina, J. M. (2012). Corporate social responsibility as a vehicle to reveal the corporate identity: A study focused on the websites of Spanish financial entities. Journal of Business Ethics, 107(2), 129-146. https://doi.org/10.1007/s10551-011-1027-2

Bunker, M., \& Ball, A. D. (2009).Consequences of customer powerlessness: Secondary control. Journal of Consumer Behaviour, 8, 268-283. https://doi.org/10.1002/cb.287

Carroll, A. B. (1979). A three-dimensional conceptual model of corporate performance. Academy of Management Review, 4(4), 497-505. https://doi.org/10.5465/AMR.1979.4498296

Carroll, A. B. (1999). Corporate social responsibility evolution of a definitional construct. Business \& Society, 38(3), 268-295. https://doi.org/10.1177/000765039903800303

Carroll, A. B., \& Shabana, K. M. (2010). The business case for corporate social responsibility: A review of concepts, research and practice. International Journal of Management Reviews, 12(1), 85-105. https://doi.org/10.1111/j.1468-2370.2009.00275.x

Chen, S. W., \& Chiu, C. H. (2011). The dual-process model of moral judgment: An integrated viewpoint of cognition, emotion, and culture. Indigenous Psychological Research in Chinese Societies, 36, 33-76. https://doi.org/10.6254/2011.36.33

Cheng, L. L. (2014). Does moral economy have a chance in consumer society? A proposal to reconfigure theory beyond the substantive/formal dichotomy. Taiwanese Journal of Sociology, 54, 181-232.

Cheung, C. M., \& Lee, M. K. (2012). What drives consumers to spread electronic word of mouth in online consumer-opinion platforms. Decision Support Systems, 53(1), 218-225. https://doi.org/10.1016/j.dss.2012.01.015

Chih, H. H., Miao, W. C., \& Chuang, Y. C. (2014). Is corporate social responsibility a double-edged sword? 
Evidence from fortune global 500 companies. Journal of Management, 31(1), 1-19. https://doi.org/10.6504/JOM.2014.31.01.01

Dahlsrud, A. (2008). How corporate social responsibility is defined: An analysis of 37 definitions. Corporate Social Responsibility and Environmental Management, 15(1), 1-13. https://doi.org/10.1002/csr.132

Elangovan, A. R., \& Shapiro, D. L. (1998). Betrayal of trust in organizations. Academy of Management Review, 23, 547-567.

Ellen, P. S., Webb, D. J., \& Mohr, L. A. (2006). Building corporate associations: Consumer attributions for corporate socially responsible programs. Journal of the Academy of Marketing Science, 34(2), 147-157. https://doi.org/10.1177/0092070305284976

Fornell, C., \& Larcker, D. F. (1981). Structural equation models with unobservable variables and measurement error: Algebra and statistics. Journal of Marketing Research, 382-388. https://doi.org/10.2307/3150980

Giannarakis, G., Litinas, N., \& Theotokas, I. (2011). A Delphi study to identify corporate social responsibility indicators: The case of Greek telecommunication sector. Journal of Sustainable Development, 4(2), 16-32. https://doi.org/10.5539/jsd.v4n2p16

Grappi, S., Romani, S., \& Bagozzi, R. P. (2013). Consumer response to corporate social irresponsible behavior: Moral emotions and virtues. Journal of Business Research, 66(10), 1814-1821. https://doi.org/10.1016/j.jbusres.2013.02.002

Gregoire, Y., \& Fisher, R. J. (2008). Customer betrayal and retaliation: When your best customers become your worst enemies. Journal of the Academy of Marketing Science, 36, $247-261$. https://doi.org/10.1007/s11747-007-0054-0

Grimmer, M., \& Bingham, T. (2013). Company environmental performance and consumer purchase intentions. Journal of Business Research, 66(10), 1945-1953. https://doi.org/10.1016/j.jbusres.2013.02.017

Groening, C., \& Kanuri, V. K. (2013). Investor reaction to positive and negative corporate social events. Journal of Business Research, 66(10), 1852-1860. https://doi.org/10.1016/j.jbusres.2013.02.006

Herzig, C., \& Moon, J. (2013). Discourses on corporate social ir/responsibility in the financial sector. Journal of Business Research, 66(10), 1870-1880. https://doi.org/10.1016/j.jbusres.2013.02.008

Jeong, H. J., Paek, H. J., \& Lee, M. (2013). Corporate social responsibility effects on social network sites. Journal of Business Research, 66(10), 1889-1895. https://doi.org/10.1016/j.jbusres.2013.02.010

Joireman, J., Gregoire, Y., Devezer, B., \& Tripp, T. M. (2013). When do customers offer firms a "second chance" following a double deviation? The impact of inferred firm motives on customer revenge and reconciliation. Journal of Retailing, 89(3), 315-337. https://doi.org/10.1016/j.jretai.2013.03.002

Jones, B., Bowd, R., \& Tench, R. (2009). Corporate irresponsibility and corporate social responsibility: Competing realities. Social Responsibility Journal, https://doi.org/10.1108/17471110910977249

Kemper, J., Schilke, O., Reimann, M., Wang, X., \& Brettel, M. (2013). Competition-motivated corporate social responsibility. Journal of Business Research, 66(10), 1954-1963. https://doi.org/10.1016/j.jbusres.2013.02.018

Koehler, J. J., \& Gershoff, A. D. (2003). Betrayal aversion: When agents of protection become agents of harm. Organizational Behavior and Human Decision Processes, 90(2), $244-261$. https://doi.org/10.1016/S0749-5978(02)00518-6

Kucuk, S. U. (2010). Negative double jeopardy revisited: A longitudinal analysis. Journal of Brand Management, 18(2), 150-158. https://doi.org/10.1057/bm.2010.27

Kurucz, E., Colbert, B., \& Wheeler, D. (2008). The business case for corporate social responsibility. In A. Crane, A. McWilliams, D. Matten, J. Moon, \& D. Siegel (Eds.), The Oxford Handbook of Corporate Social Responsibility (pp. 83-112). Oxford: Oxford University https://doi.org/10.1093/oxfordhb/9780199211593.003.0004

Lange, D., \& Washburn, N. T. (2012). Understanding attributions of corporate social irresponsibility. Academy of Management Review, 37(2), 300-326. https://doi.org/10.5465/amr.2010.0522

Lantos, G. P. (2001). The boundaries of strategic corporate social responsibility. The Journal of Consumer Marketing, 18(7), 595-630. https://doi.org/10.1108/07363760110410281 
Lee, K. H., \& Shin, D. (2010). Consumers' responses to CSR activities: The linkage between increased awareness and purchase intention. Public Relations Review, 36(2), 193-195. https://doi.org/10.1016/j.pubrev.2009.10.014

Lee, P. K., Lau, A. K., \& Cheng, T. C. E. (2013). Employee rights protection and financial performance. Journal of Business Research, 66(10), 1861-1869. https://doi.org/10.1016/j.jbusres.2013.02.007

Lin-Hi, N., \& Muller, K. (2013). The CSR bottom line: Preventing corporate social irresponsibility. Journal of Business Research, 66(10), 1928-1936. https://doi.org/10.1016/j.jbusres.2013.02.015

Lombart, C., \& Louis, D. (2014). A study of the impact of corporate social responsibility and price image on retailer personality and consumers' reactions (satisfaction, trust and loyalty to the retailer). Journal of Retailing and Consumer Services, 21(4), 630-642. https://doi.org/10.1016/j.jretconser.2013.11.009

Lu, W., Chau, K. W., Wang, H., \& Pan, W. (2014). A decade's debate on the nexus between corporate social and corporate financial performance: A critical review of empirical studies 2002-2011. Journal of Cleaner Production, 79(15), 195-206. https://doi.org/10.1016/j.jclepro.2014.04.072

Marylyn, C., \& Ahmad, A. (2001). The myth of the ethical consumer-do ethics matter in purchase behaviour? The Journal of Consumer Marketing, 18(7), 560-577. https://doi.org/10.1108/07363760110410263

Murphy, P. E., \& Schlegelmilch, B. B. (2013). Corporate social responsibility and corporate social irresponsibility: Introduction to a special topic section. Journal of Business Research, 66(10), 1807-1813. https://doi.org/10.1016/j.jbusres.2013.02.001

Oberseder, M., Schlegelmilch, B. B., \& Murphy, P. E. (2013). CSR practices and consumer perceptions. Journal of Business Research, 66(10), 1839-1851. https://doi.org/10.1016/j.jbusres.2013.02.005

Perks, K. J., Farache, F., Shukla, P., \& Berry, A. (2013). Communicating responsibility-practicing irresponsibility in CSR advertisements. Journal of Business Research, 66(10), 1881-1888. https://doi.org/10.1016/j.jbusres.2013.02.009

Prasad, A., \& Holzinger, I. (2013). Seeing through smoke and mirrors: A critical analysis of marketing CSR. Journal of Business Research, 66(10), 1915-1921. https://doi.org/10.1016/j.jbusres.2013.02.013

Ringle, C. M., Sarstedt, M., \& Straub, D. W. (2012). A critical look at the use of PLS-SEM in MIS Quarterly. MIS Quarterly, 36(1), iii-xiv.

Schoorman, F. D., Mayer, R. C., \& Davis, J. H. (2007). An integrative model of organizational trust: Past, present, and future. Academy of Management Review, 32(2), 344-354. https://doi.org/10.5465/AMR.2007.24348410

Skarmeas, D., \& Leonidou, C. N. (2013). When consumers doubt, watch out! The role of CSR skepticism. Journal of Business Research, 66(10), 1831-1838. https://doi.org/10.1016/j.jbusres.2013.02.004

Sweetin, V. H., Knowles, L. L., Summey, J. H., \& McQueen, K. S. (2013). Willingness-to-punish the corporate brand for corporate social irresponsibility. Journal of Business Research, 66(10), 1822-1830. https://doi.org/10.1016/j.jbusres.2013.02.003

Taneja, S. S., Taneja, P. K., \& Gupta, R. K. (2011). Researches in corporate social responsibility: A review of shifting focus, paradigms, and methodologies. Journal of Business Ethics, 101(3), 343-364. https://doi.org/10.1007/s10551-010-0732-6

Turker, T. (2009). Measuring corporate social responsibility: A scale development study. Journal of Business Ethics, 85(4), 411-427. https://doi.org/10.1007/s10551-008-9780-6

Urbach, N., \& Ahlemann, F. (2010). Structural equation modeling in information systems research using partial least squares. JITTA: Journal of Information Technology Theory and Application, 11(2), 5-40. https://doi.org/10.18637/jss.v048.i03

Valor, C. (2005). Corporate social responsibility and corporate citizenship: Towards corporate accountability. Business and Society Review, 110(2), 191-212. https://doi.org/10.1111/j.0045-3609.2005.00011.x

Van Marrewijk, M. (2003). Concepts and definitions of CSR and corporate sustainability: Between agency and communion. Journal of Business Ethics, 44(2-3), 95-105. https://doi.org/10.1023/A:1023331212247

Wagner, T., Bicen, P., \& Hall, Z. R. (2008). The dark side of retailing: Towards a scale of corporate social irresponsibility. International Journal of Retail \& Distribution Management, 36(2), 124-142. https://doi.org/10.1108/09590550810853075 
Walster, E., Berscheid, E., \& Walster, G. W. (1973). New directions in equity research. Journal of Personality and Social Psychology, 25(2), 151-176. https://doi.org/10.1037/h0033967

Wang, C. C., \& Wu, Y. H. (2013). Emotional episode, retaliation and altruism: Negative online word-of-mouths

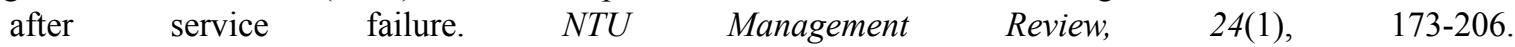
https://doi.org/10.6226/NTURM2013.JUL.C11

Wetzer, I. M., Zeelenberg, M., \& Pieters, R. (2007). "Never eat in the restaurant, I did!”: Exploring why people engage in negative word-of-mouth communication. Psychology \& Marketing, 24(8), 661-680. https://doi.org/10.1002/mar.20178

Windsor, D. (2013). Corporate social responsibility and irresponsibility: A positive theory approach. Journal of Business Research, 66(10), 1937-1944. https://doi.org/10.1016/j.jbusres.2013.02.016

Wood, D. J. (2010). Measuring corporate social performance: A review. International Journal of Management Review, 12(1), 50-84. https://doi.org/10.1111/j.1468-2370.2009.00274.x

Wu, J. (2014). The antecedents of corporate social and environmental irresponsibility. Corporate Social Responsibility and Environmental Management, 21(5), 286-300. https://doi.org/10.1002/csr.1335

\section{Copyrights}

Copyright for this article is retained by the author(s), with first publication rights granted to the journal.

This is an open-access article distributed under the terms and conditions of the Creative Commons Attribution license (http://creativecommons.org/licenses/by/4.0/). 